\title{
Identification of the constitutive ultradian oscillator of the circadian clock (ENOX1) in Saccharomyces cerevisiae
}

\author{
Sara S. Dick ${ }^{1,2}$, Aya Ryuzoji ${ }^{2}$, Dorothy M. Morré ${ }^{1,2}$, D. James Morréé, ${ }^{2, *}$ \\ ${ }^{1}$ Department of Foods and Nutrition, Purdue University, West Lafayette, USA \\ ${ }^{2}$ Mor-Nu Co., LLC, Purdue Research Park, West Lafayette, USA \\ ${ }^{3}$ Department of Medicinal Chemistry, Purdue University, West Lafayette, USA \\ Email: ${ }^{\text {dj_morre@yahoo.com }}$
}

Received 4 April 2013; revised 9 May 2013; accepted 24 May 2013

Copyright (C) 2013 Sara S. Dick et al. This is an open access article distributed under the Creative Commons Attribution License, which permits unrestricted use, distribution, and reproduction in any medium, provided the original work is properly cited.

\begin{abstract}
A yeast (Saccharomyces cerevisiae) deletion library was screened based on NADH fluorescence using a 384 well plate assay and robotics to identify a yeast isolate lacking the $\mathbf{2 4}$ min periodic cell surface oxidase. The oxidase was shown previously to be a candidate ultradian oscillator of the yeast's biological clock. The cDNA was cloned from a yeast overexpression library and the encoded protein was expressed in bacteria and characterized. Glyceraldehyde-3-phosphate dehydrogenase activity was used as the cellular circadian indicator. The identified gene was YML117W which encodes a ca $126 \mathrm{kDa}$ putative RNA-binding protein. The candidate ENOX1 activity from yeast had functional characteristics similar to those of other constitutive ENOX1 proteins of eukaryotes exhibiting oscillating activities with a temperature independent period length of $24 \mathrm{~min}$ phased by melatonin and low frequency electromagnetic fields and susceptible to inhibition by the ENOX1 inhibitor, simalikalactone $D$. The YML117W deletion mutant cells lacked the ENOX1 clock output present in wild type yeast. The findings identify YML117W as the ENOX1 of Saccharomyces cerevisiae and support its proposed function as an ultradian oscillator of the yeast biological clock.
\end{abstract}

Keywords: Biological Clock; ECTO-NOX (ENOX)

Proteins; Ultradian Oscillator;

Yeast (Saccharomyces cerevisiae)

\section{INTRODUCTION}

ECTO-NOX designates a family of cell surface proteins, exhibiting a time-keeping hydroquinone $[\mathrm{NAD}(\mathrm{P}) \mathrm{H}]$ oxi-

${ }^{*}$ Corresponding author. dase activity that alternates with a protein disulfide-thiol interchange activity [1]. The designation ECTO-NOX or ENOX recognizes their localization on the outer side of the plasma membrane [2] and distinguishes them from the phox-Nox proteins of host defense localized to the inner surface of the cell [3].

Three members of the ENOX family have been described [4]. There is a constitutive $\mathrm{NAD}(\mathrm{P}) \mathrm{H}$ oxidase (ENOX1 or CNOX) expressed in normal cells and located on chromosome 13q14.11. A tumor-associated NAD (P) H oxidase (ENOX2 or tNOX) is located on chromosome Xq25-q26.2, and is restricted to the surface of cancer cells. Both have been identified within the human genome (GenBank Accession No. EF432052 for ENOX1 [5] and AF207881 for ENOX2 [6], respectively. An agerelated $\mathrm{NAD}(\mathrm{P}) \mathrm{H}$ oxidase $(\operatorname{arNOX})$ is present only in individuals after the age of 30 , in late passage cultured cells and in senescent plants [7]. Human ENOX1 shares $64 \%$ identity and $80 \%$ similarity with human ENOX2 [5]. All three proteins contain a pyridine nucleotide-binding site, a putative protein disulfide-thiol interchange site and at least two copper-binding sites [5,8,9].

The yeast, Saccharomyce cerevisiae, has an ENOX1 activity with a period length of $24 \mathrm{~min}$ similar to that of other eukaryotes [10]. In contrast to other eukaryotes, however, S. cerevisiae has a second ENOX1-like activity with a period length of $25 \mathrm{~min}$. The latter is distinguishable from the traditional ENOX1 on the basis of the longer period length along with resistance to an ENOX1 inhibitor, simalikalactone $\mathrm{D}$, and failure to be phased by melatonin. Thus, wild type yeast produces complex patterns of oscillations often with 8 or more maxima within a 25 -min period, rather than the five peak pattern of a single ENOX1.

Deletion strains of $S$. cerevisiae were analyzed as an approach to identification of the genes responsible for the ENOX1 activity. Each of the deletion strains that 
produced a five peak pattern in the decomposition fits were analyzed. The five peak pattern indicates a loss of complexity and may indicate a deletion of the gene for one of the two ENOX1 proteins. The proteins corresponding to the deleted genes could be assayed for periodic $\mathrm{NAD}(\mathrm{P}) \mathrm{H}$ oxidase activity that was inhibited by simalikalactone D. As such, any protein with periodic NAD(P)H oxidase activity that was inhibited by simalikalactone D would represent a candidate ENOX1. Using this approach, a candidate yeast gene potentially encoding a yeast ENOX1 protein with a 24-min period where activity was inhibited by simalikalactone D was identified and characterized.

\section{METHODS}

\subsection{Saccharomyces Growth and Preparation}

Yeast were grown at room temperature with shaking in rich media (YEPD) for 1 - 2 days until saturation. The yeast strains were maintained on YEPD agar plates and stored at $4^{\circ} \mathrm{C}$. Yeast cells were inactivated by heating for $1 \mathrm{~h}$ at $70^{\circ} \mathrm{C}$ prior to assay.

\subsection{NAD(P)H Oxidase Assay}

The heat-inactivated yeast cells $\left(\sim 10^{7}\right.$ cells $)$ were added to a cuvette containing $2.5 \mathrm{ml} 50 \mathrm{mM}$ Tris-Mes buffer (pH 7.0), $2 \mathrm{mM} \mathrm{KCN}$ and $150 \mu \mathrm{M}$ NADH. GSH was added to a final concentration of $100 \mu \mathrm{M}$, and the cuvette was incubated for $10 \mathrm{~min}$. Next $\mathrm{H}_{2} \mathrm{O}_{2}$ was added to a final concentration of $0.03 \%$ and the cuvette was incubated for $10 \mathrm{~min}$. The solution was measured in a Hitachi spectrophotometer at $340 \mathrm{~nm}$, continuously for $1 \mathrm{~min}$ at $1.5 \mathrm{~min}$ intervals for $2 \mathrm{~h}$. The slopes of the continuous scans were calculated and plotted on a graph. Inhibitors were added at $60 \mathrm{~min}$ and data were collected for a further $60 \mathrm{~min}$. A second instrument with the vehicle alone added at $60 \mathrm{~min}$ served as the control. An extinction coefficient of $6.21 \mathrm{mM}^{-1} \cdot \mathrm{cm}^{-1}$ was used to calculate the specific activity [11].

\subsection{Hydroquinone Oxidation}

Reduced coenzyme $\mathrm{Q}_{10}$ was prepared fresh by addition of an equal volume of $0.25 \% \mathrm{NaBH}_{4}$ under nitrogen to a $7.5 \mathrm{mM}$ stock solution of coenzyme $\mathrm{Q}_{10}$ in ethanol. After several min of incubation, 0.1 volume of $0.1 \mathrm{~N} \mathrm{HC1}$ was added to degrade the excess $\mathrm{NaBH}_{4}$. The reaction mixture for measuring the oxidation of $\mathrm{Q}_{10} \mathrm{H}_{2}$ contained 50 $\mu l$ of heat-inactivated yeast in $2.5 \mathrm{ml}$ of $50 \mathrm{mM}$ Tris-Mes buffer, $\mathrm{pH} 7.0$. $0.08 \%$ Triton $\mathrm{X}-100$ was used to solubilize the $\mathrm{Q}_{10} \mathrm{H}_{2}$ in the assay buffer. The reaction was started with the addition of $40 \mu \mathrm{l}$ of $5 \mathrm{mM} \mathrm{Q}_{10} \mathrm{H}_{2}$. The disappearance of reduced CoQ was measured at both $290 \mathrm{~nm}$ and $410 \mathrm{~nm}$. An extinction coefficient of $0.805 \mathrm{mM}^{-1} \cdot \mathrm{cm}^{-1}$ was used to calculate the rate of $\mathrm{Q}_{10} \mathrm{H}_{2}$ oxidation [12].

\subsection{DTDP Cleavage}

Heat-inactivated yeast were added to $2.5 \mathrm{ml}$ of reaction buffer (50 mM Tris-Mes, $\mathrm{pH} 7.0)$. The reaction was preincubated with $0.5 \mu \mathrm{mol}$ of 2.2 '-dithiodipyridine (DTDP) in $5 \mu \mathrm{l}$ DMSO. After $10 \mathrm{~min}$ of incubation, a further 3.5 $\mu \mathrm{mol}$ of DTDP were added in $35 \mu \mathrm{l}$ of DMSO to start the reaction. The increase in absorbance due to the cleavage of DTDP was monitored at $340 \mathrm{~nm}$. The specific activity of the cleavage reaction was calculated using a millimolar absorption coefficient of $6.21 \mathrm{~cm}^{-1}$ [13].

\subsection{NADH Fluorescence}

As YEPD medium is fluorescent, heat-inactivated yeast cells were washed with PBS by centrifuging the cells in the bench top mini centrifuge (VWR, Pennsylvania) for 2 min, the supernatant was discarded and the pellet was resuspended in PBS. This suspension was used for measurements of NADH fluorescence.

The inactivated yeast suspension in PBS was added to wells of a black 96-well plate at a dilution of 1:10 in a volume of $20 \mu \mathrm{l}$. The PBS for the experiment was supplemented with $2 \%$ glucose. The plate was loaded into a Fluoroskan fluorescent plate reader and the samples were measured once every min for $2 \mathrm{~h}-8 \mathrm{~h}$, with excitation at $355 \mathrm{~nm}$ and emission at $460 \mathrm{~nm}$. Data were analyzed by Fast Fourier Transform (Minitab 15) and decomposition analysis (Minitab 15) [14].

\subsection{GAPDH Assays}

Yeast were grown in SD-ura or SG-ura media on a shaker at room temperature for 2 - 3 days. $50 \mu \mathrm{l}$ of each culture were taken every $2 \mathrm{~h}$ and snap frozen at $-80^{\circ} \mathrm{C}$. To prepare the samples for the assay, the yeast were thawed and $50 \mu \mathrm{l}$ of Y-PER Yeast Protein Extraction Reagent (Pierce) was added and the solution was vortexed for $20 \mathrm{~min}$ to lyse the yeast and release the proteins. Glyceraldehyde-3-phosphate dehydrogenase activity was assayed in a reaction solution containing $100 \mu \mathrm{l}$ yeast lysate, $0.1 \mathrm{M}$ Tris-HC1, $0.5 \mathrm{mM}$ EGTA, $\mathrm{pH}$ 8.0, 1 $\mathrm{mM} \mathrm{Na}_{2} \mathrm{HAsO}_{4}, 2 \mathrm{mM} \mathrm{NAD}^{+}$and $3 \mathrm{mM}$ glyceraldehyde-3-phosphate. $\mathrm{NAD}^{+}$reduction was determined from the increases in absorbance at $340 \mathrm{~nm}$ at $37^{\circ} \mathrm{C}$ [15] measured over $5 \mathrm{~min}$. A millimolar extinction coefficient of $6.21 \mathrm{~cm}^{-1}$ was used to calculate NADH disappearance.

\section{RESULTS}

\subsection{Deletion Library Screen}

The yeast deletion library of non-essential genes was screened by NADH fluorescence and analyzed with decomposition fits. A total of 4846 strains were screened. 
NADH fluorescence of each strain was analyzed by fitting the data to a $24 \mathrm{~min}$ period and inspecting the resulting graphs for loss of complexity compared to the wild-type parent strain. The parent strain exhibited at least 7 or more maxima in the decomposition fits (Figure 1(a)).

Each decomposition fit was inspected and the maxima were counted. Thirty-two candidate genes with the requisite number of 5 maxima when deleted yielded one strain with protein properties consistent with its identity as an ENOX1 gene when the gene was overexpressed and the resultant protein was isolated and characterized. The yeast strain YML117W (Figure 1(b)) emerged from these studies as a candidate ENOX1 protein of Saccharomyces cerevisiae.

YM117W, located on chromosome 13, encodes a 1134 aa protein of molecular weight 126,138 and isoelectric point 6.99 (Figure 2). It contained a G926GGETG putative adenine binding motif (GXGXXG) and Y503GH and 1061YNH and H556XXH putative copper binding motifs. Potential protein disulfide motifs included C802XXXXM and C303XXXXXXC.

More important, the YML117W gene product when overexpressed and analyzed did exhibit all of the properties associated with the ENOX1 protein of other species. There were essentially no homologies between the amino acid sequence of the YML117W and human ENOX1 or

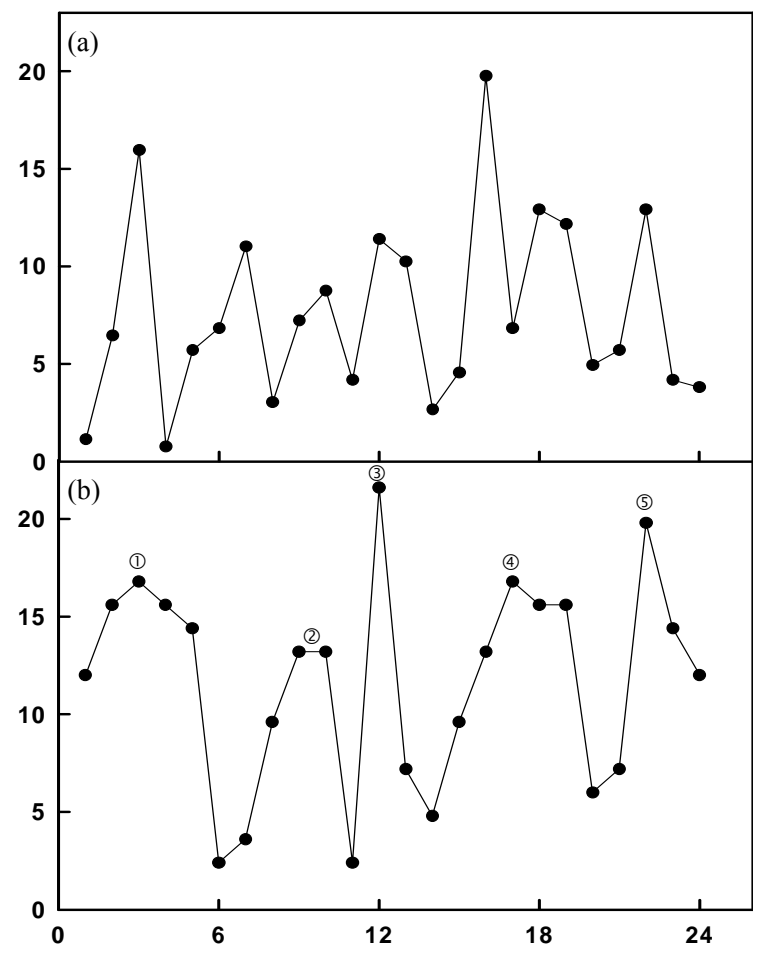

Figure 1. NADH fluorescence decompositions fits. (a) Wild type yeast strain showing a pattern of 7 maxima; (b) YML117W showing a pattern of 5 maxima. human ENOX2 proteins.

Sliced and pulverized SDS-PAGE gels from which the protein was eluted overnight in ENOX assay buffer revealed enzymatic activity only in the region of the gel occupied by full-length YML117W ENOX1 (Figure 3).

\subsection{NADH Oxidase Assays}

When subjected to standard NADH oxidase activity assays in which the disappearance of NADH was measured over $1 \mathrm{~min}$ at $1.5 \mathrm{~min}$ intervals, $24 \mathrm{~min}$ periods of active-

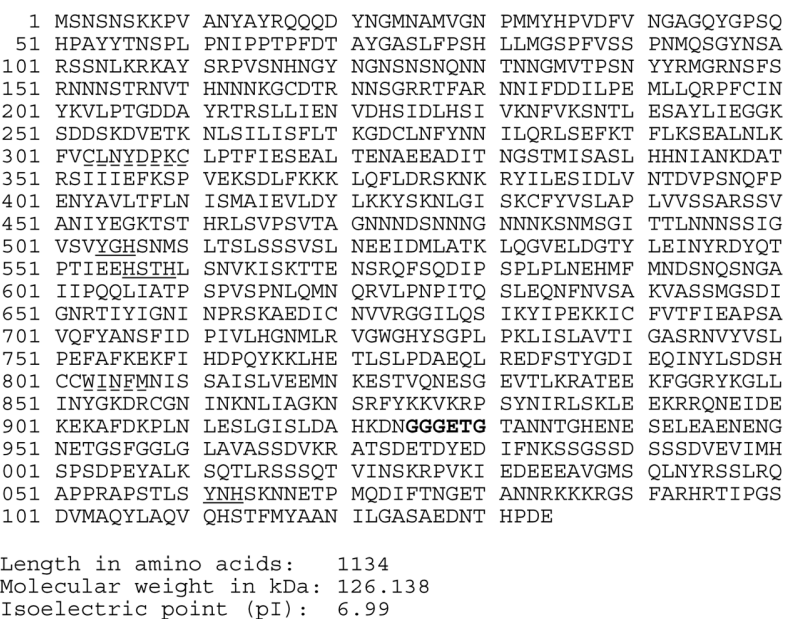

Figure 2. Sequence of YML117 W. A putative NADH-binding is bolded, potential protein disulfide-thiol interchange sites are denoted by dashed underlines and putative copper-binding sites are underlined.

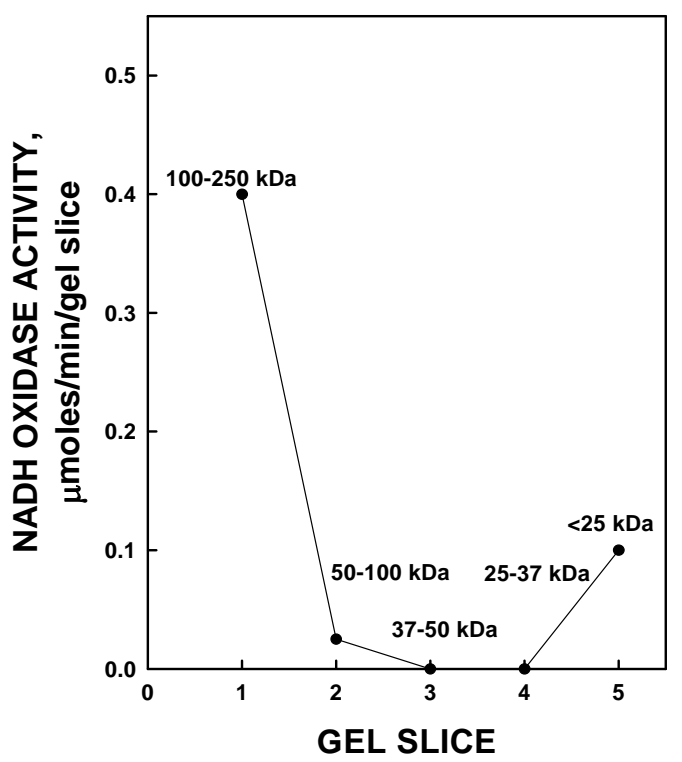

Figure 3. Resolution of recombinant His-tagged ENOX1 by SDS-PAGE. Eluted activity was restricted to the high molecular weight region of the gel consistent with a molecular weight of 126,960 daltons with the His tag. 
ity were revealed in which the first two oxidative peaks separated by 6 min denoted by (1) and (2) were evident in all assays (Figure 4). The second set of oscillations, with a period length of 25 min observed in wild type yeast [10], was absent. Further, the activity of the candidate yeast ENOX1 protein was inhibited completely by the ENOX1 inhibitor simalikalactone D.

The period lengths of YML117W NADH oxidation were temperature independent and did not change over the range of $17^{\circ} \mathrm{C}$ to $37^{\circ} \mathrm{C}$ (Table 1). In contrast, the amplitude of the period approximately doubled with every $10^{\circ} \mathrm{C}$ increase in temperature.

\subsection{Simalikalactone D}

An extract from the leaves and bark of the Quassia amara L. tree contains the compound, simalikalactone D, that inhibits the activity of ENOX1 in mammalian and plant preparations [16]. When an extract containing simalikalactone D was added to the NADH oxidase assay, the activity of the 24 min ENOX1 period of purified yeast YML117W NADH activity was completely inhibited (Figure 4) confirming the purified ENOX as an ENOX1.

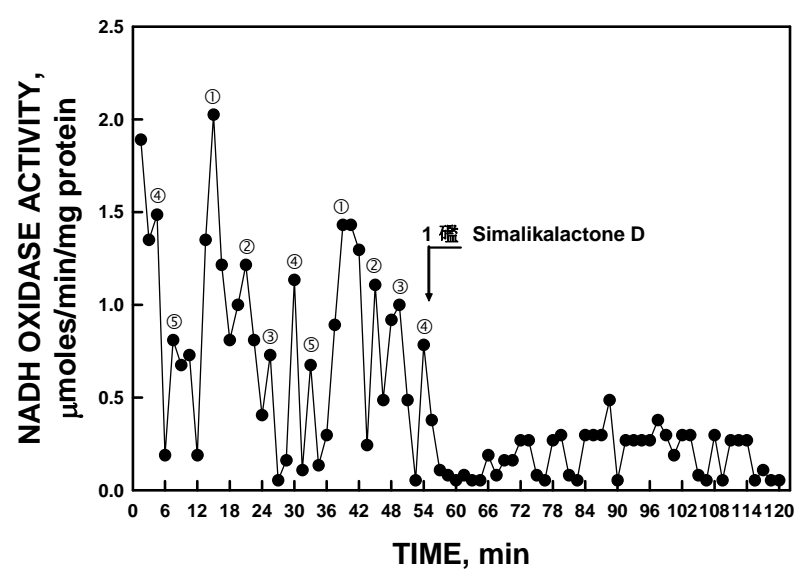

Figure 4. Oxidation of NADH by recombinant YML117-W and inhibition by the ENOX1-specific inhibitor simalikalactone D. Maxima labeled (1) and (2) are separated from each other by $6 \mathrm{~min}$ whereas maxima labeled (3), (4) and (5) are separated from each other and from maxima (1) and (2) by 4.5 $\min$ to produce a $24-\mathrm{min}$ period $[6 \min +(4 \times 4.5 \mathrm{~min})]$.

Table 1. ENOX1 period length of Saccharomyces cerevisiae is independent of temperature $(n=4)$.

\begin{tabular}{ccc}
\hline Temperature & Period length $^{1}$ & Amplitude $^{2}$ \\
\hline $17^{\circ} \mathrm{C}$ & $24 \mathrm{~min}$ & $0.22 \pm 0.05$ \\
$27^{\circ} \mathrm{C}$ & $24 \mathrm{~min}$ & $0.48 \pm 0.09$ \\
$37^{\circ} \mathrm{C}$ & $24 \mathrm{~min}$ & $1.0 \pm 0.10$ \\
\hline
\end{tabular}

${ }^{1}$ Period length monitored over time intervals as long as $6 \mathrm{~h}$ varied with a cumulative error of less than one $\mathrm{min} .{ }^{2}$ Nanomoles $/ \mathrm{min} / 10^{6}$ cells.

\subsection{Circadian Day}

Circadian periodicity based on measurements of glyceraldehyde-3-phosphate dehydrogenase (GAPDH) activity is revealed by the presence of a $24 \mathrm{~h}$ oscillation (Figure 5) and a maximum which may represent the $40 \mathrm{~h}$ period of autonomous metabolic oscillations (See Discussion). No evidence of a second ENOX1 period of $25 \mathrm{~h}$ corresponding to that found in wild-type yeast was seen.

\subsection{Response to Melatonin}

Melatonin shifts the period of ENOX1 in mammalian cells. When melatonin (final concentration $10 \mu \mathrm{M}$ ) was added to the NADH oxidase assay of purified YML117W ENOX1, a new maximum of NADH oxidase activity appeared exactly $24 \mathrm{~min}$ after melatonin addition (Figure 6).

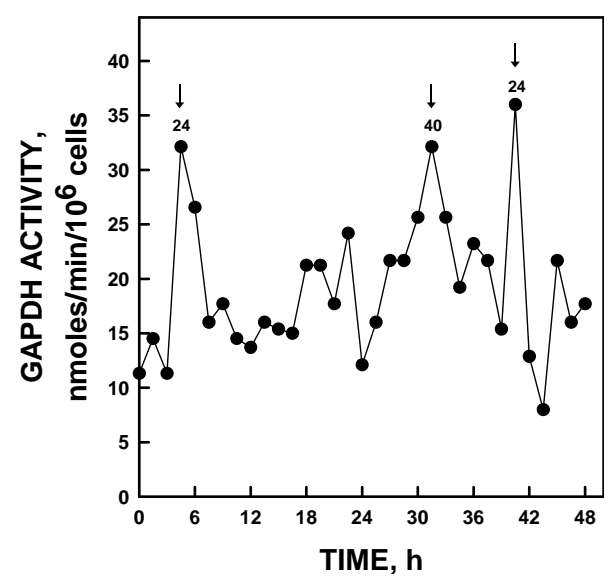

Figure 5. GAPDH activity of yeast grown in glucose. GAPDH activity peaked at intervals of $24 \mathrm{~h}$ and $40 \mathrm{~h}$. The $40 \mathrm{~h}$ maxima appears to correspond to the 40 min period normally observed only with continuous cultures [19-21].

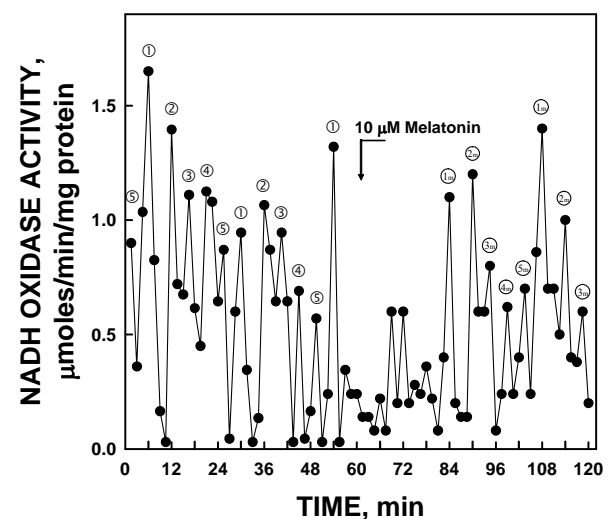

Figure 6. The activity period of NADH oxidation by recombinant YML117W was phased by the addition of melatonin. The 24 min activity (1) and (2) separated by 6 min was shifted to recur $24 \mathrm{~min}$ after melatonin addition ( $1 \mathrm{~m}$ and $2 \mathrm{~m}$ ). 


\subsection{Low-Frequency Electromagnetic Fields}

The period of purified yeast YML117W ENOX based on rate of NADH oxidation was shifted by application of low-frequency electromagnetic fields (50 uT for $20 \mathrm{sec}$ ) to the assay cuvette. A control cuvette assayed in parallel was protected in a Faraday cage. The low-frequency electromagnetic field (EMF) resulted in a phase shift of the ENOX1 pattern of activity (Figure 7). The control (non-exposed) ENOX1 period was not shifted.

\subsection{Hydroquinone Oxidation}

When hydroquinone oxidation was assayed as an example of a more natural, membrane-located, substrate compared to NADH, a single set of 5 maxima were seen (Figure 8) similar to those observed with NADH.

\subsection{DTDP Cleavage}

Protein disulfide-thiol interchange activity as measured by cleavage of the substrate 2',2'-dithiodipyridine (DTDP) (Figure 9). Mammalian ENOX1 produces 3 maxima of DTDP cleavage separated by $4.5 \mathrm{~min}$. A single set of 3 maxima each separated by $4.5 \mathrm{~min}$, labeled (3), (4)

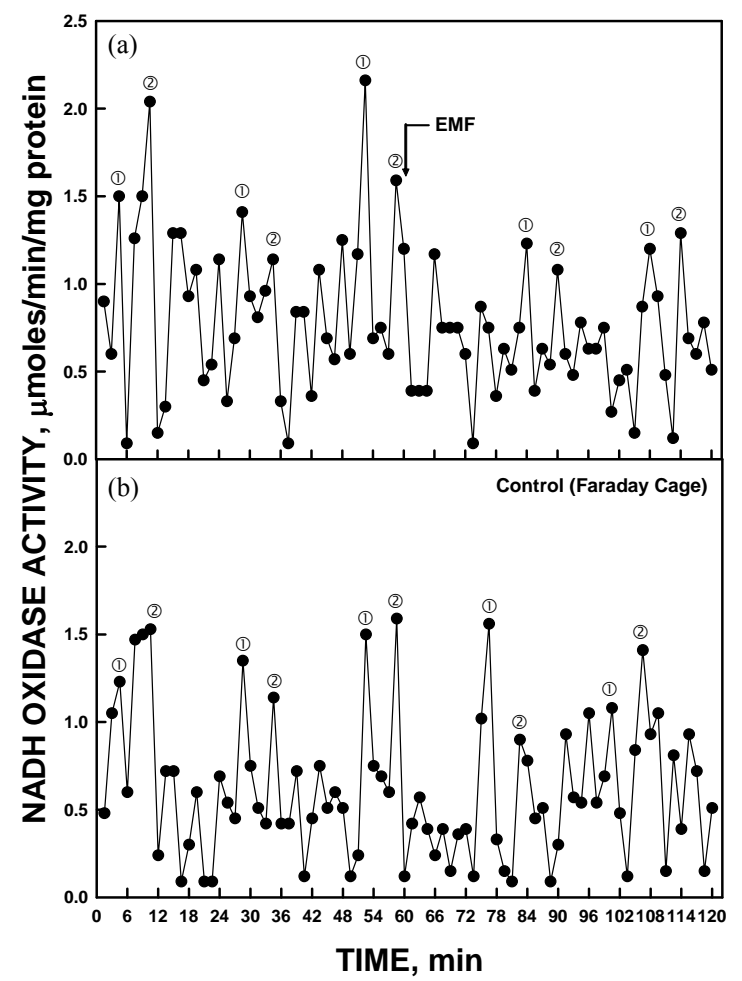

Figure 7. The activity period of NADH oxidation was phased by the application of low-frequency EMF applied at 60 min (a). A control cuvette, protected by a Faraday cage, was assayed in parallel in a second spectrophotometer (b). All maxima were shifted approximately $7.5 \mathrm{~min}$ by the $20 \mathrm{sec}$ EMF exposure to $50 \mu \mathrm{T}$ relative to the control preparation.

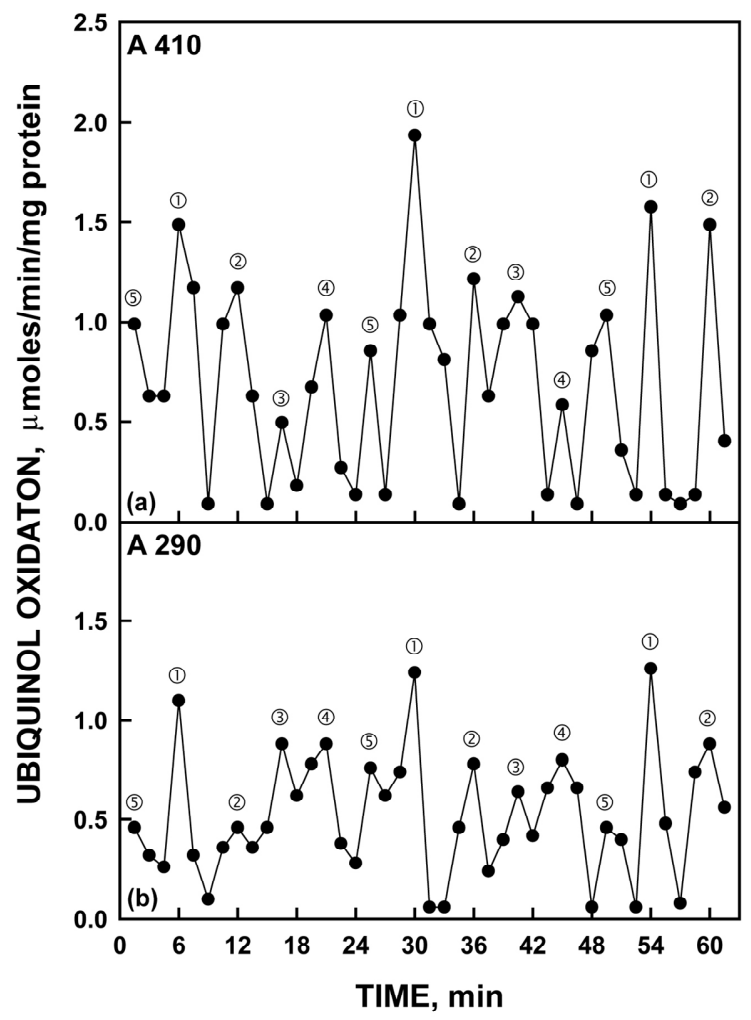

Figure 8. Oxidation of reduced coenzyme Q by recombinant YML117W measured either by an increase in A210 (a) or by a decrease in A290 (b). As with NADH oxidation of Figure 4, the activity oscillated with prominent maxima separated by 6 min (1) and (2) followed by 3 additional maxima separated by $4.5 \mathrm{~min}$ to generate the 24-min period.

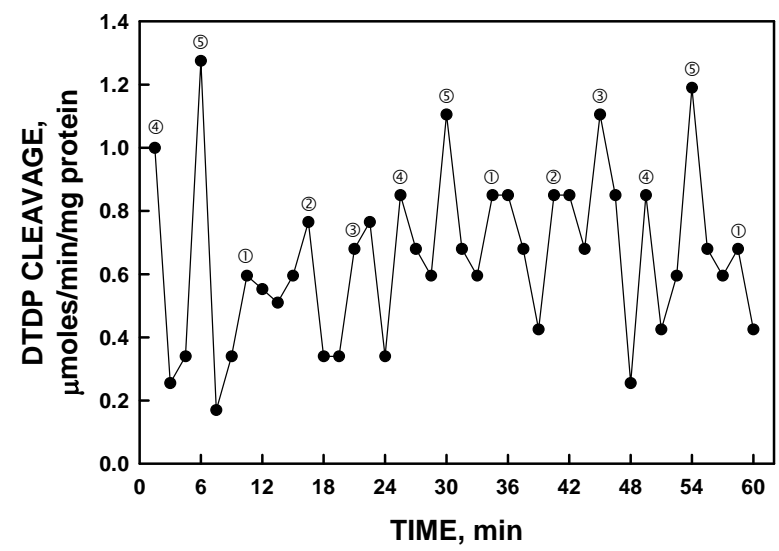

Figure 9. Recombinant YML117W exhibited disulfide thiol interchange activity determined from the cleavage of a synthetic dithodipyridine (DTDP) substrate. The spacing of labeled maxima is the same as that of Figure 4. However, in contrast, maxima labeled (3), (4) and (5) separated by $4.5 \mathrm{~min}$ are generally of greater amplitude than maxima (1) and (2) separated by $6 \mathrm{~min}$.

and (5) of slightly higher amplitude that alternates with the 2 peaks of the oxidative activity. 


\subsection{Copper Dependence}

The mammalian form of ENOX1 contains copper and copper is essential for its activity (Figure 10). In the presence of the copper chelator bathocuproine, little or no oscillatory activity was observed (Figure 10(b)). In these experiments with purified yeast YML117W, ENOX was assayed in the presence of trifluoroacetic acid to unfold the protein (Figure 10(a)). When unfolded in the presence of bathocuproine, activity was diminished (Figure 10(b)). TFA alone did not reduce activity and activity could be restored to TFA and bathocuproine treated preparations by addition of copper (Figure 10(c)).

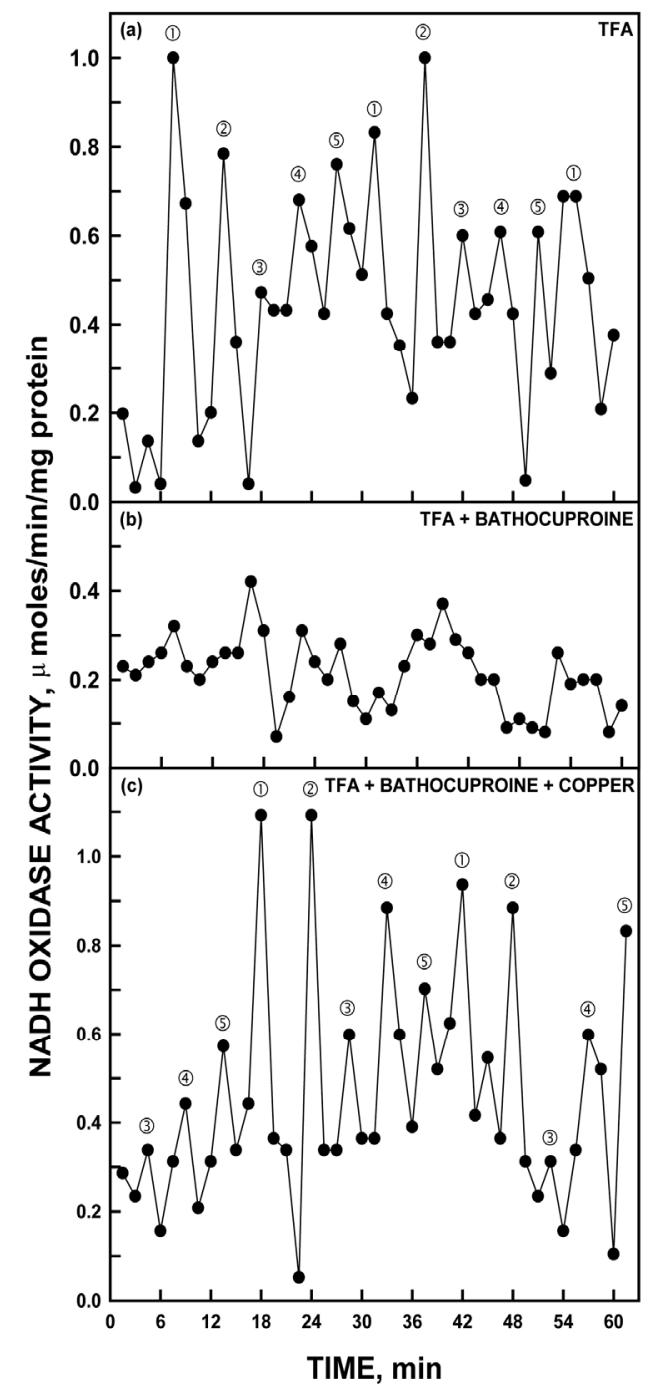

Figure 10. NADH oxidase activity of recombinant YML117W diminished with TFA + bathocuproine. (a) In the presence of TFA, the $24 \mathrm{~min}$ period was unaffected; (b) When assayed with TFA and bathocuproine, the 24 min period was much reduced; (c) Removal of bathocuproine by dialysis and readdition of copper restored full activity.

\subsection{Protease Resistance}

A hallmark of the ENOX family of proteins is that of protease resistance [17]. To determine if the yeast ENOX1 isoforms were resistant to proteases, they were assayed after digestion with proteinase $\mathrm{K}$ or trypsin, and it was found that the activity was very little affected (Table 2) including when trifluoroacetic acid was used to unfold the protein in an attempt to render it more susceptible to digestion.

\subsection{Period Length in Deuterium Oxide}

Heat-inactivated purified YML117W yeast ENOX1 assayed in heavy water yielded a pattern of activities with period lengths of approximately $30 \mathrm{~min}$ (Figure 11).

\section{DISCUSSION}

ECTO-NOX proteins differ from other NAD(P)H oxidases in that they reduce pyridine nucleotides in the absence of bound flavin [6]. Moreover, their activity is not inhibited by cyanide [11]. In addition, ECTO-NOX proteins have properties of trans-plasma membrane electron transport, which transfers reducing equivalents from cytosolic $\mathrm{NAD}(\mathrm{P}) \mathrm{H}$ to external acceptors, including molecular oxygen and protein disulfide. ENOX1 and ENOX2

Table 2. Protease resistance of yeast ENOX1 and response to capsaicin.

\begin{tabular}{cc}
\hline Treatment & Specific Activity, $\mu$ moles $/ \mathrm{min} / \mathrm{mg}$ Protein \\
\hline None & $1.23 \pm 0.06$ \\
Proteinase K & $1.17 \pm 0.06$ \\
Trypsin & $1.16 \pm 0.06$ \\
Capsaicin & $1.18 \pm 0.04$ \\
\hline
\end{tabular}

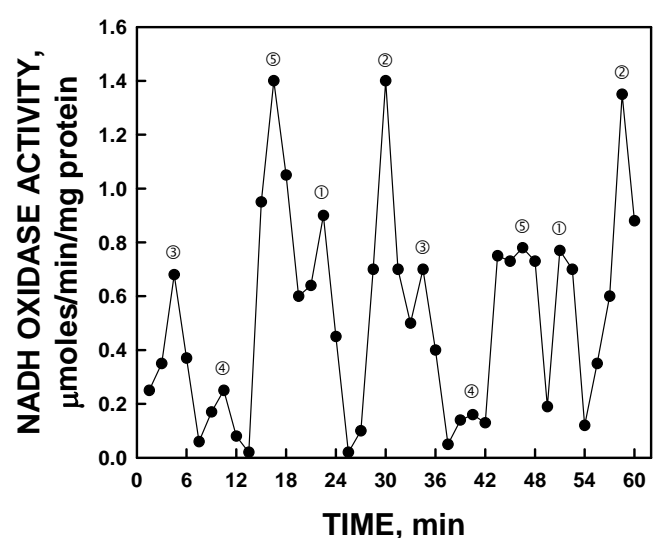

Figure 11. NADH oxidase activity of YML117W when assayed in $\mathrm{D}_{2} \mathrm{O}$ exhibited an increase in period length from $24 \mathrm{~min}$ to $30 \mathrm{~min}$. The effect of heavy water to increase period length is one of the hallmarks of the biological clock (see text). 
both lack iron or iron sulfur clusters, but sequence analysis reveals motifs to be the potential copper binding sites necessary for electron transfer to molecular oxygen. Based on size exclusion chromatography, the soluble forms of ENOX2 are predominantly dimers, such that the ENOX proteins may be viewed as dimeric proteins containing four coppers per dimer, thus carrying out four electron transfers to molecular oxygen as required to form water $[4,5,8]$.

ECTO-NOX proteins exhibit a second catalytic activeity involving protein disulfide-thiol interchange although the CXXC motif (common to most members of the protein disulfide isomerase family) is missing. The two activities, NADH oxidation and protein disulfide-thiol interchange, alternate with a period length that is characteristic for each family member. ENOX1 exhibits oscillations with period lengths of $24 \mathrm{~min}$. Several lines of evidence indicate that ECTO-NOX proteins are involved in at least two important cell functions. They drive the enlargement phase of cell growth and they are components of the cell's biological clock. The second biological function, the regulation of the circadian oscillatory system, is ascribed mainly to ENOX1. The two enzymatic activities catalyzed by ENOX1 alternate within a 24-min period. The first activity rests after $12 \mathrm{~min}$ and the second one begins in a cycle that confers the time-keeping function. This oscillation pattern (which is also entrainable and temperature independent) is considered to be clock-related. Cells transfected with mutated ENOX cDNAs to generate ENOX1 proteins with oscillation period lengths of 22,36 or 42 min exhibited circadian period lengths of 22,36 or $42 \mathrm{~h}$ for the circadian biochemical marker glyceraldehyde-3-phosphate dehydrogenase [18].

In this report, we have studied the constitutive ENOX1 activities of $S$. cerevisiae which has properties of a biological clock protein and ultradian rhythm of about 24 min. A mutant yeast strain exhibiting only one ENOX1 activity with a 24-min period was sought and identified as YML117W. The YML117W ENOX1 protein catalyzed both the oxidation of NADH to $\mathrm{NAD}^{+}$alternating with protein disulfide-thiol interchange. This pattern of alternating activities is unique to the ENOX proteins and that of Saccharomyces cerevisiae is similar to that of the mammalian ENOX1 [5].

The statistical validity of the asymmetric non-sinusoidal oscillatory activity pattern has been validated previously by Fast Fourier and decomposition (seasonal forecasting) analyses [14]. Each $24 \mathrm{~min}$ period exhibits 5 maxima, 2 of which are separated by 6 min designated (1) and (2) and the remainder of which, designated (3), (4) and (5), are separated from each other and from maximum (1) by $4.5 \mathrm{~min}(6+4(4.5)=24 \mathrm{~min})$ [4]. Upon addition of melatonin, the yeast ENOX1 exhibits new maxima, (1) and (2) separated by $6 \mathrm{~min}$, exactly 24 min after melatonin addition. The activity was blocked by simalikalactone $\mathrm{D}$ as is characteristic of mammalian ENOX1 [5]. As the ENOX activities of yeast are at the external surface of the plasma membrane, activity may be measured with intact cells using NADH, a membrane impermeant substrate.

The $24 \mathrm{~h}$ rhythm in GAPDH activity corresponded to the 24 min ENOX1 rhythm, as observed with other organisms, and accounts for one of the two ENOX activities demonstrated previously for heat-inactivated yeast [10].

Among the first defined clock-related oscillations was the 40 min cycle of dissolved oxygen levels in continuous culture [19-24]. Also seen in these data was evidence for the 40 min metabolic period (not shown).

As yeast enlarge by tip growth, or budding $[25,26]$, the role of ENOX1 in physical membrane displacements essential to cell enlargement [27-29] is apparently unessential such that deletion mutants could be used to identify the ENOX1 of S. cerevisiae as YML117W. The activity of the YML117W ENOX1 protein is protease and heat $\left(80^{\circ} \mathrm{C}\right)$ resistant in keeping with data from mammalian sources [30-32]. The period length was lengthened to about $30 \mathrm{~min}$ in assays where water was replaced by $\mathrm{D}_{2} \mathrm{O}$ as is generally characteristic of the circadian clock [33,34] and was phased by melatonin ([35], Figure 6) and by exposure to low frequency electromagnetic fields ([36], Figure 7).

The identification of the ENOX form with the 25-min period which is insensitive to simalikalactone $\mathrm{D}$ and melatonin as YDR005C will be the subject of a subsequent publication.

\section{REFERENCES}

[1] Morré, D.J. and Morré, D.M. (2003) Cell surface NADH oxidases (ECTO-NOX proteins) with roles in cancer, cellular time-keeping, growth, aging and neurodegenerative disease. Free Radical Research, 37, 9795-9808. doi:10.1080/1071576031000083107

[2] Morré, D.J. (1995) NADH oxidase activity of HeLa plasma membranes inhibited by the anticancer sulfonylurea $\mathrm{N}$-(4-methylphenylsulfonyl)-N-(4chloro-phenyl) urea (LY181984) at an external site. Biochimica et Biophysica Acta, 1240, 201-208.

doi:10.1016/0005-2736(95)00199-9

[3] Lambeth, J.D., Cheng, G., Arnold, R.S. and Edens, W.A. (2000) Novel homologs of gp91phox. Trends in Biological Sciences, 25, 459-461. doi:10.1016/S0968-0004(00)01658-3

[4] Morré, D.J. and Morré, D.M. (2012) ECTO-NOX proteins. Springer, New York, 507 pp.

[5] Jiang, Z., Gorenstein, N.M., Morré, D.M. and Morré, D.J. (2008) Molecular cloning and characterization of a can- 
didate human growth-related and time-keeping constitutive cell surface hydroquinone (NADH) oxidase. Biochemistry, 47, 14028-14038. doi:10.1021/bi801073p

[6] Chueh, P.J., Kim, C., Cho, N., Morré, D.M. and Morré, D.J. (2002) Molecular cloning and characterization of a tumor-associated, growth-related and time-keeping hydroquinone (NADH) oxidase (NOX) of the HeLa cell surface. Biochemistry, 41, 3732-3741. doi:10.1021/bi012041t

[7] Morré, D.J., Guo, F. and Morré, D.M. (2003) An agingrelated cell surface NADH oxidase (arNOX) generates superoxide and is inhibited by coenzyme Q. Molecular and Cellular Biochemistry, 254, 101-109. doi:10.1023/A:1027301405614

[8] Tang, X., Chueh, P.J., Jiang, Z., Layman, S., Martin, B, Kim, C., et al. (2010) Essential role of copper in the activity and regular periodicity of a recombinant, tumorassociated, cell surface, growth-related and time-keeping hydroquinone (NADH) oxidase with protein disulfidethiol interchange activity (ENOX2). Journal of Bioenergetics and Biomembrances, 42, 355-360.

[9] Tang, X., Parisi, D., Spicer, B., Morré, D.M. and Morré, D.J. (in Press) Molecular cloning and characterization of human age-related NADH oxidase (arNOX) proteins as members of the TM9 superfamily of transmembrane proteins. Advances in Biological Chemistry.

[10] Dick, S.S., Ryuzoji, A., Morré, D.M. and Morré, D.J. (2013) Ultradian oscillators of the circadian clock in Saccharomyces cerevisiae. Advances in Biological Chemistry, 3, 59-69. doi:10.4236/abc.2013.31008

[11] Brightman, A.O., Wang, J., Miu, R.K., Sun, I.L., Barr, R., Crane, F.L., et al. (1992) A growth factor- and hormone-stimulated NADH oxidase from rat liver plasma membrane. Biochimica et Biophysica Acta, 1105, 109117. doi:10.1016/0005-2736(92)90168-L

[12] Kishi, T., Morré, D.M. and Morré, D.J. (1999) The plasma membrane NADH oxidase of HeLa cells has hydroquinone oxidase activity. Biochimica et Biophysica Acta, 1412, 66-77. doi:10.1016/S0005-2728(99)00049-3

[13] Morré. D.J., Gomez-Rey, M.L., Schramke, C., Em, O., Lawler, J., Hobeck, J. and Morré, D.M. (1999) Use of dipyridyl-dithio substrates to measure directly the protein disulfide-thiol interchange activity of the auxin stimulated NADH: Protein disulfide reductase (NADH oxidase) of soybean plasma membranes. Molecular Cellular Biochemistry, 200, 7-13. doi:10.1023/A:1006916116297

[14] Foster, K., Anward, N., Pogue, R., Morré, D.M., Keenan, T.W. and Morré, D.J. (2003) Decomposition analyses applied to a complex ultradian biorhythm: The oscillating NADH oxidase activity of plasma membranes having a potential time-keeping (clock) function. Nonlinearity in Biology, Toxicology and Medicine, 1, 51-70. doi:10.1080/15401420390844465

[15] Shinohara, M.L., Loros, J.J. and Dunlap, J.C. (1998) Glyceraldhyde-3-phosphate is regulated on a daily basis by the circadian clock. Journal of Biological Chemistry, 273, 446-452. doi:10.1074/jbc.273.1.446

[16] Morré, D.J. and Greico, P.A. (1999) Glaucarubolone and simalikalactone $\mathrm{D}$, respectively, preferentially inhibit auxin-induced and constitutive components of plant cell enlargement and the plasma membrane NADH oxidase. International Journal of Plant Science, 160, 291-297. doi:10.1086/314133

[17] Kelker, M., Kim, C., Chueh, P.J., Guimont, R., Morré, D.M. and Morré, D.J. (2001) Cancer isoform of a tumor-associated cell surface NADH oxidase (tNOX) has properties of a prion. Biochemistry, 40, 7351-7354. doi:10.1021/bi010596i

[18] Morré, D.J., Chueh, P.J., Pletcher, J., Tang, X., Wu, L.Y. and Morré, D.M. (2002) Biochemical basis for the biological clock. Biochemistry, 41, 11941-11945. doi:10.1021/bi020392h

[19] Murray, D.B., Roller, S., Kuriyama, H. and Lloyd, D. (2001) Clock control of ultradian respiratory oscillation found during yeast continuous culture. Journal of Bacteriology, 183, 7253-7259.

[20] Murray, D.B., Klevecz, R.R. and Lloyd, D. (2003) Generation and maintenance of synchrony in Saccharomyces cerevisiae continuous culture. Experimental Cell Research, 287, 10-15. doi:10.1016/S0014-4827(03)00068-5

[21] Lloyd, D., Eshantha, L., Salgado, J., Turner, M.P. and Murray, D.B. (2002) Respiratory oscillations in yeast: clock-driven mitochondrial cycles of energization. FEBS Letters, 519, 41-44. doi:10.1016/S0014-5793(02)02704-7

[22] Satroutdinov, A.D., Kuriyama, H. and Kobayashi, H. (1992) Oscillatory metabolism of Saccharomyces cerevisiae in continuous culture. FEMS Microbiology Letters, 98, 261-268. doi:10.1111/j.1574-6968.1992.tb05525.x

[23] Keulers, M., Suzuki, T., Satroutinov, A.D. and Duriyama, H. (1996) Autonomous metabolic oscillation in continuous culture of Saccharomyces cerevisiae grown on ethanol. FEMS Microbiology Letters, 142, 253-258. doi:10.1111/j.1574-6968.1996.tb08439.x

[24] Klevecz, R.R., Bolen, J., Forrest, G. and Murray, D.B. (2004) A genome wide oscillation in transcription gates DNA replication and cell cycle. Proceedings of the $\mathrm{Na}$ tional Academy of Sciences USA, 101, 1200-1205.

[25] Adams, A.E. and Pringle, J.R. (1984) Relationship of actin and tubulin distribution to bud growth in wild-type and morphogenetic-mutant Saccharomyces cerevisiae. Journal of Cellular Biology, 98, 934-945. doi:10.1083/jcb.98.3.934

[26] Cabib, E., Bowers, B., Sburlati, A. and Silverman, S.J. (1988) Fungal cell wall synthesis: The construction of a biological structure. Microbiology Sciences, 5, 370-375.

[27] Morré, D.J., Kim, C. and Hicks-Berger, C. (2006) ATPdependent and drug inhibited vesicle enlargement reconstituted using synthetic lipids and recombinant proteins. BioFactors, 28, 105-117. doi:10.1002/biof.5520280205

[28] Hicks-Berger, C. and Morré, D.J. (2006) Inside-out but not right side-out plasma membrane vesicles from soybean enlarge when treated with ATP + 2,4-D as determined by electron microscopy and light scattering: evidence for involvement of a plasma membrane AAAATPase. BioFactors, 28, 91-104. doi:10.1002/biof.5520280204 
[29] Auderset, G. and Morré, D.J. (2006) ATP- and growth substance-dependent cell-free enlargement of plasma membrane vesicles from soybean. BioFactors, 28, 83-90. doi:10.1002/biof.5520280203

[30] Chueh, P.J., Morré, D.J., Wilkinson, F.E., Gibson, J. and Morré, D.M. (1997) A $33.5 \mathrm{kDa}$ heat-and protease resistant NADH oxidase inhibited by capsaicin from sera of cancer patients. Archives of Biochemistry and Biophysics, 342, 38-47. doi:10.1006/abbi.1997.9992

[31] del Castillo-Olivares, A., Yantiri, F., Chueh, P.J., Wang, S., Sweeting, M., Sedlak, D., et al. (1998) A drug-responsive and protease-resistant peripheral NADH oxidase complex from the surface of HeLa S cells. Archives of Biochemistry and Biophysics, 358, 125-140. doi:10.1006/abbi.1998.0823

[32] Sedlak, D., Morré, D.M. and Morré, D.J. (2001) A drugunresponsive and protease-resistant CNOX protein from human sera. Archives of Biochemistry and Biophysics, 386, 106-116. doi:10.1006/abbi.2000.2180
[33] Enright, J.T. (1997) Heavy water slows biological timing processes. Zeitschrift für vergleichende Physiologie, 72, 1-16. doi:10.1007/BF00299200

[34] Bruce, V.G. and Pittendrigh, C.S. (1960) Temperature independence in unicellular "clock". Journal of Cellular and Comparative Physiology, 56, 25-31. doi:10.1002/jep.1030560105

[35] Morré, D.J. and Morré, D.M. (2003) The plasma membrane-associated NADH oxidase (ECTO-NOX) of mouse skin responds to blue light. Journal of Photochemistry and Photobiology B, 70, 7-12. doi:10.1016/S1011-1344(03)00023-X

[36] Morré, D.J., Jiang, Z., Marjanovic, M., Orczyk, J. and Morré, D.M. (2008)) Response of the regulatory behavior of Copper ${ }^{\mathrm{II}}$ containing ECTO-NOX proteins and $\mathrm{Cu}^{\mathrm{II}} \mathrm{Cl}_{2}$ in solution to electromagnetic fields. Journal of Inorganic Biochemistry, 102, 1812-1818. doi:10.1016/j.jinorgbio.2008.06.001 